\title{
New faunistic records of Salticidae (Aranei) from Khorasan Province of Iran
}

\section{Новые фаунистические находки Salticidae (Aranei) из иранской провинџии Хорасан}

\author{
D.V. Logunov ${ }^{1}$, O. Mirshamsi' ${ }^{2}$ S. Musavi ${ }^{3}$ \& A. Shayestehfar ${ }^{3}$

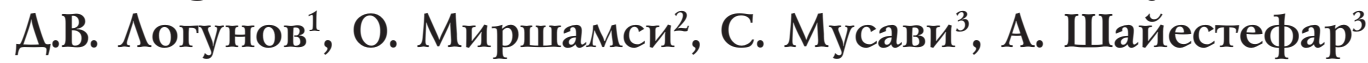

\footnotetext{
${ }^{1}$ The Manchester Museum, The University of Manchester, Manchester, M13 9PL, UK. Email: dmitri.v.logunov@manchester.ac.uk. The corresponding author.

${ }^{2}$ Department of Biology, Faculty of Sciences, Ferdowsi University of Mashhad, Mashhad, Islamic Republic of Iran.

${ }^{3}$ Department of Biology, Faculty of Sciences, Arak University, Arak, Islamic Republic of Iran.
}

KEY WORDS: Jumping spiders, Salticidae, Aranei, Iran, faunistics, new records, distribution.

КЛЮЧЕВЫЕ СЛОВА: пауки-скакунчики, Salticidae, Aranei, Иран, новые находки, фаунистика, распространение.

ABSTRACT. New faunistic records of nine species of Salticidae for the spider fauna of Iran are presented. Four species - Heliophanus chovdensis Prószyński, 1982, Pseudicius afghanicus (Andreeva, Hęciak et Prószyński, 1984), Rafalus variegatus (Kroneberg, 1875), and Sitticus avocator (O. Pickard-Cambridge, 1885) — are new records for the spider fauna of Iran.

РЕЗЮМЕ. Даны новые фаунистические находки девяти видов из семейства Salticidae фауны Ирана. Четыре вида — Heliophanus chovdensis Prószyński, 1982, Pseudicius afghanicus (Andreeva, Hęciak et Prószyński, 1984), Rafalus variegatus (Kroneberg, 1875), and Sitticus avocator (O. Pickard-Cambridge, 1885) — впервые отмечены для фауны Ирана.

\section{Introduction}

The Salticidae fauna of Iran currently includes 80 species of 35 genera [Mozaffarian \& Marusik, 2001; Logunov et al. 2002, 2007; Azarkina, 2002; Ghavami, 2006, 2007; Logunov, 2007, 2009, 2010; Ghahari \& Marusik, 2009; etc.] and it is safe to assume that this fauna still remains poorly known (see Logunov [2010] for a discussion). Here, we present data on new faunistic records for nine spider species of the Salticidae from various localities in Khorasan Province, one of the least studied territories of Iran (see Mirshamsi [2005] for a provisional list of 95 spider species of 26 families), based on the material newly collected by one of us (SM). Despite its small size, the studied salticid collection has yielded four new species records for the spider fauna of Iran (see below).

One additional species $\left(1 \sigma^{\gamma}\right.$ in poor condition; MMUM) remains undetermined. It is Phlegra sp. from the bresnieri species group taken from the following locality: Iran, Torbate Haydarieh - Mashhad road, Dugheshk $\left(35.3055^{\circ} \mathrm{N}, 59.2436^{\circ} \mathrm{E}\right), 1377 \mathrm{~m}$ a.s.1., 26.05 . 2012, S. Musavi. It does not belong to true P. bresnieri (Lucas, 1846) [sensu Logunov \& Azarkina, 2006] because it does not have the dense white hairs on the clypeus. This male may belong to $P$. particeps (Pickard-Cambridge, 1872), a poorly known species reported from the Near East to Bhutan [Prószyński, 2003]. A proper identification of our male is impossible until the entire bresnieri species group has been thoroughly revised.

The specimens examined are preserved in the following collections: ZMFUM - Zoological Museum, Ferdowsi University of Mashhad, Mashhad, Islamic Republic of Iran (Dr O. Mirshamsi); and MMUM The Manchester Museum, University of Manchester, Manchester, UK (Dr D.V. Logunov).

\section{Results}

Bianor albobimaculatus (Lucas, 1846)

MATERIAL. $3 \sigma^{7} \sigma^{7}$ (ZMFUM), Khorasan Prov., Sarakhs, Bazangan $\left(36.3097^{\circ} \mathrm{N}, 60.4694^{\circ} \mathrm{E}\right), 861 \mathrm{~m}$ a.s.1., 18.06 .2012 , S. Musavi.

COMMENTS. This species is known from South Africa to the Mediterranean, with Algeria and Portugal being the westernmost limits of the range, and northeastward to Central Asia [Logunov, 2001a, 2009].

\section{Heliophanus chovdensis Prószyński, 1982}

MATERIAL. $1 \sigma^{7}$ (palp) 1 (MMUM), Khorasan Prov., c. 17 $\mathrm{km}$ NW of Mashhad, Tous $\left(36.4713^{\circ} \mathrm{N}, 59.5138^{\circ} \mathrm{E}\right), 1004 \mathrm{~m}$ a.s.1., 23.04.2012, S. Musavi; $1 \sigma^{\top}$ (ZMFUM), Khorasan Prov., Mashhad, Razavieh $\left(36.250^{\circ} \mathrm{N}, 59.769^{\circ} \mathrm{E}\right), 951 \mathrm{~m}$ a.s.1, 27.09.2012, S. Musavi.

COMMENTS. To date, this species has been known from SE Kazakhstan, Kyrghyzstan and W Mongolia only [Rakov \& Logunov, 1996; Logunov \& Marusik, 
2000b: map 21]. Thus, the finding of $H$. chovdensis in Khorasan significantly extends the species' range and lies in its SW limit. New record for Iran.

Heliophanus mordax (O. Pickard-Cambridge, 1872)

MATERIAL. $1 \mathrm{O}^{7}$ (ZMFUM), Khorasan Prov., c. $17 \mathrm{~km}$ NW of Mashhad, Tous $\left(36.488^{\circ} \mathrm{N}, 59.505^{\circ} \mathrm{E}\right), 1004 \mathrm{~m}$ a.s.1., 23.04.2012, S. Musavi.

COMMENTS. It is an east Mediterranean - Central Asian subboreal species, known from Egypt and Greek islands in the west [Metzner, 1999], throughout Asia Minor and the Near East [Prószyński, 2003; Topçu et al., 2006], to the Caucasus and Central Asia, as far as SW Kopetdagh [Rakov \& Logunov, 1996] and Khorasan Province of Iran [present data].

\section{'Hyllus' insularis Metzner, 1999}

MATERIAL. $10^{7}$ (ZMFUM), Khorasan Prov., Torbate Haydarieh $\left(35.2636^{\circ} \mathrm{N}, 59.1891^{\circ} \mathrm{E}\right), 1367 \mathrm{~m}$ a.s.1., 25.06.2012, S Musavi.

COMMENTS. To date, this species has been known from Greece (Lesbos Isl.) and Iran (Tehran, Yazd, Mazandaran and Khorasan Provinces) only [Metzner, 1999; Logunov, 2001b; present data]. Khorasan Province lies in the easternmost limit of the currently known species' range.

\section{Langona pallidula Logunov et Rakov, 1998}

MATERIAL. $1 \sigma^{7}$ (MMUM), Khorasan Prov., Torbate Haydarie $\left(35.7666^{\circ} \mathrm{N}, 59.25^{\circ} \mathrm{E}\right), 1367 \mathrm{~m}$ a.s.1., 14.05 .2012 , S. Musavi.

COMMENTS. To date, this species has been known from the type locality (Turkmenistan: Repetek) only [Logunov \& Rakov, 1998]. However, our identification should be considered provisional, as the difficult genus Langona Simon, 1901 requires a complete taxonomic revision. The present record may also belong to L. aperta (Denis, 1958) known only from a few localities in Afghanistan [Logunov \& Zamanpoore, 2005]. The matter requires special attention in the future when more comparative material of both sexes from Iran has been collected.

Pseudicius afghanicus (Andreeva, Hęciak et Prószyński, 1984)

MATERIAL. 1 ( (MMUM), Khorasan Prov., Gonabad $\left(34.1369^{\circ} \mathrm{N}, 58.6455^{\circ} \mathrm{E}\right), 1100 \mathrm{~m}$ a.s.1., 5.09.2012, S. Musavi.

COMMENTS. It is a poorly known species described from Afghanistan (Nangarhar Prov.) and then recorded from SE Kazakhstan, Uzbekistan and W China (Xinjiang) [Logunov \& Rakov, 1998]. New record for Iran.

\section{Rafalus variegatus (Kroneberg, 1875)}

MATERIAL. 1 (ZMFUM), Khorasan Prov., Sarakhs, Mazdavand $\left(36.143^{\circ} \mathrm{N}, 60.5166^{\circ} \mathrm{E}\right), 929 \mathrm{~m}$ a.s.1., 17.06.2012, S. Musavi; $1 \sigma^{7}$ (ZMFUM), Khorasan Prov., Khalaj Mts $\left(36.2291^{\circ} \mathrm{N}\right.$, $\left.59.5727^{\circ} \mathrm{E}\right), 1147 \mathrm{~m}$ a.s.1., 8.04.2012, S. Musavi; $2 \sigma^{7} \sigma^{\top}(\mathrm{ZM}$
FUM), Khorasan Prov., Mashhad, Sang Bast $\left(35.9833^{\circ} \mathrm{N}\right.$, $\left.59.7510^{\circ} \mathrm{E}\right), 1110 \mathrm{~m}$ a.s.1., 3.05.2012, S. Musavi.

COMMENTS. It is a common species known to date from SE mountainous regions of Central Asia (SE Kazakhstan, Uzbekistan, Kyrghyzstan, E Turkmenistan and Tajikistan) [Logunov \& Rakov, 1998: map 1]. New record for Iran, lying in the south-westernmost limit of the species' range.

Salticus tricinctus (C.L. Koch, 1846)

MATERIAL. 1 ㅇ (ZMFUM), Khorasan Prov., Fariman $\left(35.6833^{\circ} \mathrm{N}, 59.8438^{\circ} \mathrm{E}\right), 1440 \mathrm{~m}$ a.s.1., 3.05.2012, S. Musavi; $1 \mathrm{O}^{7}$ (ZMFUM), Khorasan Prov., Sarakhs, Bazangan $\left(36.3097^{\circ} \mathrm{N}\right.$, $\left.60.4694^{\circ} \mathrm{E}\right), 861 \mathrm{~m}$ a.s.1., 18.06 .2012 , S. Musavi.

COMMENTS. It is a common Turanian species known from Azerbaijan and NW Iran in the west [Logunov et al., 2002] throughout Turkmenistan and southern Kazakhstan [Logunov \& Rakov, 1998: map 10] to Afghanistan in the east [Logunov \& Zamanpoore, 2005].

Sitticus avocator (O. Pickard-Cambridge, 1885)

MATERIAL. $10^{T} 1$ क (ZMFUM), Sarakhs, Shirtapeh $\left(36.1019^{\circ} \mathrm{N}, 61.228^{\circ} \mathrm{E}\right), 362 \mathrm{~m}$ a.s.1., 24.03.2012, S. Musavi.

COMMENTS. This species seems to be restricted to the mountainous regions of Central Asia only [Logunov \& Marusik, 2000a]. New record for Iran, lying in the south-westernmost limit of the species' range.

ACKNOWLEDGEMENTS. The financial support was provided by the Iran National Science Foundation (INSF90001780) which is gratefully acknowledged.

\section{References}

Azarkina G.N. 2002. New and poorly known species of the genus Aelurillus Simon, 1884 from Central Asia, Asia Minor and the eastern Mediterranean (Araneae: Salticidae) // Bull. Br. Arachnol. Soc. Vol.12. No.6. P.249-263.

Ghahari H., Marusik Yu.M. 2009. New data on spider fauna of Iran (Araneae) // Turk. J. Arachnol. Vol.2. No.3. P.1-8.

Ghavami S. 2006. Renewed checklist of spiders (Aranei) of Iran // Pakistan J. Biol. Sci. Vol.9. No.10. P.1839-1851.

Ghavami S. 2007. Spider fauna in Caspian Region of Iran // Pakistan J. Biol. Sci. Vol.10. No.5. P. 682-691.

Logunov D.V. 2001a. A redefinition of the genera Bianor Peckham \& Peckham, 1885 and Harmochirus Simon, 1885, with the establishment of a new genus Sibianor gen. n. (Araneae: Salticidae) // Arthropoda Selecta. Vol.9 (for 2000). No.4. P.221286.

Logunov D.V. 2001b. New and poorly known species of the jumping spiders (Araneae: Salticidae) from Afghanistan, Iran and Crete // Arthropoda Selecta. Vol.10. No.1. P.59-66.

Logunov D.V. 2009. Further notes on the Harmochireae of Africa (Araneae, Salticidae, Pelleninae) // Stoev P., Dunlop J., Lazarov S. (eds.). A life caught in a spider2 s web. Papers in arachnology in honour of Christo Deltshev. ZooKeys. Vol.16. P.265-290.

Logunov D.V. 2010. Taxonomic notes on a collection of jumping spiders from Iran (Araneae, Salticidae) // Bull. Br. arachnol. Soc. Vol.15. Pt.3. P.85-90.

Logunov D.V., Azarkina G.N. 2006. New species and records of Phlegra from Africa (Araneae, Salticidae) // Revue suisse de Zoologie. T.113. Fasc.4. P.727-746. 
Logunov D.V., Marusik Yu.M. 2000a. Miscellaneous notes on Palaearctic Salticidae (Arachnida: Aranei) // Arthropoda Selecta. Vol.8 (for 1999). No.4. P.263-292.

Logunov D.V., Marusik Yu.M. 2000b. Catalogue of the jumping spiders of northern Asia (Arachnida, Araneae, Salticidae). Moscow: KMK Scientific Press. 299 pp.

Logunov D.V., Marusik Yu.M., Mozaffarian F. 2002. Faunistic review of the jumping spiders of Iran (Aranei: Salticidae) // Arthropoda Selecta. Vol.10 (for 2001). No.2. P.155-167.

Logunov D.V., Rakov S.Yu. 1998. Miscellaneous notes on Middle Asian jumping spiders (Aranei: Salticidae) // Arthropoda Selecta. Vol.7. No.2. P.117-144.

Logunov D.V., Vazirianzadeh B., Moravvej S.A., Navidpour S. 2007. New faunistic records of the jumping and crab spiders (Araneae: Salticidae, Thomisidae and Philodromidae) from Iran // Arthropoda Selecta. Vol.15 (for 2006). No.3. P.225228.

Logunov D.V., Zamanpoore M. 2005. Salticidae (Araneae) of Afghanistan: an annotated check-list, with descriptions of four new species and three new synonyms // Bull. Br. arachnol. Soc. Vol.13. Pt.6. P.217-232.
Metzner H. 1999. Die Springspinnen (Araneae, Salticidae) Griechenlands // Andrias. Bd.14. S.1-279.

Mirshamsi O. 2005. Faunistic studies of spiders in Khorasan Province, Iran (Arachnida, Araneae) // Iranian J. Anim. Biosystematics. Vol.1. No.1. P.59-66.

Mozaffarian F., Marusik Yu.M. 2001. A checklist of Iranian spiders (Aranei) // Arthropoda Selecta. Vol.10. No.1. P.67-74.

Prószyński J. 2003. Salticidae (Araneae) of the Levant // Ann. zool. Warszawa. T.53. P.1-180.

Rakov S.Yu., Logunov D.V. 1996. A critical review of the genus Heliophanus C.L. Koch, 1833, of Middle Asia and the Caucasus (Aranei Salticidae) // Arthropoda Selecta. Vol.5. No.3/4. P.67-104.

Topçu A., Demir H., Seyyar O., Türkeş T. 2006. The spider fauna of the Gülek Pass (Turkey) and its environs (Araneae) // Deltshev C. \& Stoev P. (eds.). European Arachnology 2005. Acta Zoological Bulgarica. Suppl. No.1. P.287-195.

Responsible editor K.G. Mikhailov 